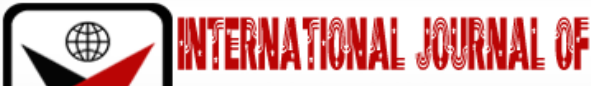

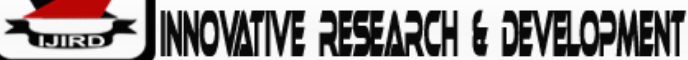

ISSN 2278-0211 (Online)

\section{Extensiveness of the Procedures Followed by Science Teachers in Preparing School Based Assessment Tools for Science Subjects in Secondary Schools in Kilimanjaro Region, Tanzania}

\begin{tabular}{|c|}
\hline Adam Joseph Chidyau \\
Ph.D. Candidate, Department of Education, Mwenge Catholic University, Tanzania \\
Timothy Mandila \\
Lecturer, Department of Education, Mwenge Catholic University, Tanzania \\
Paschal Wambiya \\
Senior Lecturer, Department of Education, Mwenge Catholic University, Tanzania \\
\hline
\end{tabular}

\begin{abstract}
:
This study investigated the extensiveness of the procedures followed by science teachers in preparing SBA tools for science subjects in secondary schools in Kilimanjaro region, Tanzania. The reviewed literature indicated that ambiguity in following procedures for developing SBA tools resulted in to lack of assessment formative aspects in SBA practices, and hence there was a need of establishing a way forward. Guided by complex adaptive system theory, it was important to examine and explore the manner in which procedures for developing SBA tools were adopted and used by science teachers in enhancing teaching and learning processes in secondary schools in the region. This mixed method study adopted an embedded model of the convergent mixed research design whereby quantitative and qualitative data sets were collected concurrently. The target population involved science teachers teaching physics, chemistry and biology subjects, students, academic masters/mistresses, head masters/mistresses, district education officers and zonal quality assurers. Stratified, convenient and purposeful sampling techniques were used to determine the study sample that consisted of 913 respondents. Questionnaires, interview guides, interview schedule, observation guide and document analysis guide were used to collect the required information. The collected data were analyzed by descriptive statistics and inferentially using Chi-square and one way ANOVA techniques. Tables, charts, narrations and direct quotations were used to present the study findings. The study concluded that despite science teachers' efforts, enthusiasm and diligence in integrating various techniques, there are no general procedures followed in order to develop and administer SBA tools formatively. However, SBA practices are comparable in public and private schools. The study recommended education stakeholders to device clear guidelines for development and administration of SBA tools in preparing SBA tasks.
\end{abstract}

Keywords: School-based assessment (SBA), procedures, SBA tools, SBA practices and science subjects

\section{Introduction}

Formal curriculum is a prescribed content to be taught and learned which provides the basis for assessment in form of testing or examination. Objectives, assessment and instruction are inseparable entities of the formal curriculum in facilitating science subjects teaching and learning processes (Porter \& Smithson, 2001). The intended curriculum refers to standards, policy guidelines and tools that outline the objectives and what science teachers are expected to teach. In Tanzania, the objectives which are also referred to as taught curriculum (English, 2010) are mandated by TIE while the assessed curriculum through continuous and final assessments are coordinated by NECTA (NECTA, 2003). Instruction as part of the enacted or taught curriculum submits to the actual science curricular content that is delivered to learners in the classroom in secondary schools. This is where most of the learning in science subjects are expected to happen and science teachers ought to carefully select various aspects of the science subjects teaching units for implementation.

Science subject teachers as key implementers of SBA in secondary schools should to be skillful enough to handle SBA practices formatively. Among others, science teachers need to identify procedures to follow in order to develop effective SBA tools containing students' tasks. Science teachers who are qualified to teach in secondary schools in Tanzania are supposed to possess a Diploma or Degree in Education in their respective science subjects i.e. biology, chemistry and physics (MoEVT, 2014). Teacher training colleges prepare Diploma teachers while Universities prepare Degree teachers in two and three years respectively. Teacher education programs provide pre-service science teachers with subject related courses and a compulsory exposure to the real classroom teaching through teaching practicum in order to equip science teachers with all necessary experiences in both teaching and SBA practices in secondary schools. 
The latest Education Sector Development Program (ESDP) 2016/17 - 2020/21 built on the premises of the Tanzania Development Vision 2025, the National Five-Year Development plan 2016/2017 - $2020 / 21$ and the Training Policy of 2014, advocates for quality education at all levels. ESDP puts more emphasis on quality of science education provision including instruction and assessment (MoEST, 2017).The ESDP objective of making productive citizens could be achieved through incorporating assessment formative aspects (AFA) in SBA practices of science subjects. This important component of formative assessment can be ensured when interactive procedures of developing and administering SBA tools are established and followed in secondary schools (Nichols \& Harris, 2016).

The question that remains unanswered is the intentional commitment of science subjects' teachers and students posed by SBA practices in secondary schools as they run-through assessment for learning every now and then in the course of teaching. In this study, SBA is considered as assessment for learning (AfL) as opposed to assessment of learning (AoL). The focus of AfL is to monitor learning, tackle the immediate students' challenges and give feedback that can help teachers and students develop insights on how to go about the formal curriculum in order to convene the demand of the present and future generation (Barnes, Fives \&Decey, 2016; Fulmer, Lee \& Tan, 2015).

Therefore, the focus of the SBA practices calls for identification of the procedures followed by science teachers to develop and administer SBA tools or tasks to students in secondary schools. The complexity and extensiveness of the procedures followed by science teachers in composing and verifying the SBA tools is still an area in the education system that is yet to be stretched out and well understood. This study therefore needed to find out the extensiveness of the procedures followed by science teachers in preparing SBA tools for science subjects in secondary schools in Kilimanjaro region.

\subsection{Statement of the Problem}

Assessment of students is a very critical practice as it lays grounds for teachers to develop evidence-based decisions about instructional implementation (McMillan, 2008; Bonner, 2016). School based assessment (SBA) practices which are formative by nature (Kyaruzi, Strijbos, Ufer\& Brown, 2019 and Taras, 2009) were not introduced in order to replace continuous assessments (CAs) which are contended to have improved ordinary level education in Tanzania (MoEVT, 2013; Ndalichako, 2014; Paulo, 2015). The study by Ottevanger, Akker\&Feiter (2007) indicated that most SubSaharan African countries including Tanzania integrated SBA practices in teaching and learning of all subjects including science subjects.

This study focused on SBA of science subjects since assessment in secondary schools is a key component not only in achieving science curriculum objectives (Biggs, 1996; Black \& William, 1998; NECTA, 2019) but also in influencing science subject teaching and learning process (NECTA 2004; Hawe\& Dixon, 2017). Testing and all sorts of students' evaluations at the school level were found to be mainly summative, teacher centered and with low student involvement instead formative as intended (Zembazemba, 2017). The latter impedes threats to the existence and practicability of SBA practices in the education systems in Tanzania and other countries in Africa at large. It is a high time now to find out procedures followed by science teaches in order to assist these countries to adopt a working SBA system that can formatively provide feedback which enhances teaching and learning of science subjects. This study therefore examined extensiveness of the procedures followed by science teachers in developing SBA tool in secondary schools in Kilimanjaro region.

\subsection{Research Question and Hypotheses}

This study was guided by one research question and two hypotheses as follows:

What procedures do secondary school teachers follow in preparing SBA tools in Kilimanjaro region?

- $\mathrm{H}_{0} 1$ : There is no significant difference in proportion towards science teachers' views on the availability of specific procedures followed in developing SBA tools in public and private secondary schools in Kilimanjaro region.

- $\mathrm{H}_{0}$ 2: There is significant agreement mean score difference on the procedures followed in developing SBA tools between categories of years of teaching experience of science teachers in secondary schools in Kilimanjaro region.

\subsection{Theoretical Framework}

The study was anchored in complex adaptive system theory, referred to as complexity theory developed by Prigogine and improved by Lorenz in early 1980s (Schneider \& Somers, 2006). The theory is originally generated in natural sciences (biology, chemistry and physics) in studying the rise of the complex systems and functioning of the living organism systems in adapting changes in the environment to increase the survivability of macro-structures (Hayles, 1990; Kauffman, 1993). It was later used to explain emergence of complex behavior in social organizations(Kelly, 2011; Terra \& Passador, 2015).The key concept of complexity theory is that living things migrate to a state of dynamic stability at the 'edge of chaos' to sustain themselves and have enough creativity to survive. The edge of chaos is the zone where complex systems can be distinguished from rigid ordered systems with creativity (Waldrop, 1993).

The theory asserts that systems can emerge as (a) self-organizing systems that spontaneously emerge without being designed from outside; (b) adaptive systems where changes are based on experiences; (c) dynamic systems which are poised on the edges of chaos as they are stable enough to maintain their structure, but are sensitive to external changes; and (d) co-evolved systems that evolve together with the systems they are interacting with or engage in the systems. Although a school organization differs from typical natural science systems, the use of a complex adaptive system theory was helpful in this study for explaining how the procedures for developing SBA tools or tasks emerged and adapted in the lower secondary school setting in Kilimanjaro region. 


\section{Literature Review}

In view of school-based assessment practices, various studies established the need for developing SBA tasks by following various structures for the reason that when assessment procedures were embraced and continued, students developed more skills and deeper understanding (Mkpae (2017). Procedures for carrying out a particular task in assessment needed to be put clear as this could facilitate its judgment as to whether the procedure is correctly implemented or not (Olufunmilayo, Adikwu\&Ipoyi, 2016). This was the heart of this study to find out extensiveness of the procedures used to develop SBA tools in order to improve teaching and learning of science subjects in secondary schools in Kilimanjaro region.

Studied also indicated that the procedures followed in preparing SBA tools were merely linear steps that gave no room for constructive dialogues between teachers, instructional materials and the learners. Factors hindering teachers from following procedures were found to be uptake of the SBA policy that provided evidence of the importance of studying both the teachers' prior or existing beliefs about assessment and the contextual factors, understand the motives behind the teachers' actual assessment practices and their attitudes towards assessment reforms (Nair, Setie, Samad, Zahiri, Luquman, Vadeveloo \& Ngah, 2014; O’Malley, Wolf-Prusan, Lima, Xiong\&Swarts, 2019; Jonglai, 2017). The studies however failed to account for the suitable procedure of conducting SBA practices, most especially the aspect of SBA tools development due to the complexity of the assessment systems.

It was the focus of this study to reveal practical procedures that could be used by science teachers in secondary school in order to make SBA practices formative. Most of the examined studies were specific on various subjects like English language, geography, economics and mathematics (Khatab, 2012;Opara, Onyekuru \& Njoku, 2015; Kyaruzi, Strijbos, Ufer\& Brown, 2019;Friyatmi, Rahmi\& Haryanto,2020). The literatures specified the necessity of improving quality of teaching and assessment for learning by ensuring existence of procedures for development of measurement instruments and tasks involved. This showed that SBA tasks of various subjects were not reflecting formativity of students since they were short of assessment formative aspects and hence denoted as lacking assessment for learning qualities (Kapambwe, 2010). Thus, the current study sought to identify the procedures used by science teachers in preparing SBA tools or tasks in teaching and learning of science subjects in Kilimanjaro region.

\section{Research Methodology}

This study adopted a mixed method approach under which the embedded model of the convergentmixedresearch design was used for the purpose of complementing quantitative and qualitative data sets (Creswell \& Creswell, 2018; Creswell, 2009 and Creswell \& Plano-Clark, 2018).The region has 346 0-level secondary schools in 7 districts of which 219 are government owned and 127 are privately owned. The sample for the study was 35 secondary schools in 7 districts of Kilimanjaro region. A total sample of 913 respondents comprised of 665 students, 170 science teachers, 35 head masters/mistresses, 35 academic masters/mistresses, 6 district education officers and 2 zonal quality assurers. Stratified random sampling, convenient and purposive sampling techniques were used to draw the sample for the study. Information for this study was collected using questionnaires for science teachers, students and academic masters/mistresses; interview schedule for head masters/mistresses; in-depth interview guides for district education officers and zonal school quality assurers; classroom observation guide and document analysis guide in order to ensure triangulation of the various responses.

Content and face validity of the instruments was determined by research experts and reliability of the questionnaire was tested by Cronbach Alpha technique. Cronbach Alpha coefficient of 0.848, 0.855 and 0.886were obtained for science teachers, students, academic masters/mistresses' questionnaires respectively while coefficient of0.915 was obtained for interview schedule for head masters/mistresses. Trustworthiness of the qualitative data was ensured by triangulation and member checking. Descriptive and inferential statistics were used for quantitative data analysis. Summary of data were presented in frequencies and percentages through tables and bar graph. Hypotheses were tested at 0.05 significance level for Chi-Square and one way ANOVA techniques. Qualitative data was analyzed by transcription of data from interviews, direct quotations were drawn and interpretation done according to the context.

\section{Findings and Discussions}

The research question intended to determine the procedures tailed by science teachers in secondary schools to prepare SBA tasks. The information pursued in this question was to identify procedures that were adopted and followed by science teachers to prepare and administer SBA tasks to science students in secondary schools in Kilimanjaro region. Identification of the procedures and skills possessed by science teachers to develop and administer SBA tasks to science students were alleged important aspects of the question that were answered by science teachers, students, academic masters/mistresses and head masters/mistresses who are the stakeholders of SBAs in secondary schools.

It was important for the researcher to collect information about these aspects so as to establish the connection between procedures followed in preparing SBA tasks and formativity of SBA practices. The aim of seeking this information was to verify whether SBA tasks prepared for science subjects in secondary schools passed through the right procedures that enhance formation of science students in the direction of planned, enacted or assessed curriculum.

\subsection{Identification of the Procedures Followed to Prepare SBA Tasks}

This section of the second research question was designed to disclose procedures used or adopted by science teachers to prepare and develop and administer SBA tasks in secondary schools. Information to address this question was attained from science teachers, students, academic masters/mistresses, head masters/mistresses, DEOs and ZQA. The researcher begun by inquiring from head masters/mistresses, science teachers and academic masters/mistresses whether 
there were specific procedures that were adopted and followed in development and administration of SBA tasks in their schools. Results are presented and described first then followed by supportive results from other respondents. Table 1 presents responses from heads masters/mistresses, science teachers and academic masters/mistresses on whether procedures for developing SBA tasks exist in secondary schools.

\begin{tabular}{|c|c|c|c|c|c|c|}
\hline Variable & \multicolumn{2}{|c|}{$\begin{array}{c}\text { Head } \\
\text { Masters/Mistresses }\end{array}$} & \multicolumn{2}{c|}{$\begin{array}{c}\text { Science } \\
\text { Teachers }\end{array}$} & \multicolumn{2}{c|}{$\begin{array}{c}\text { Academic } \\
\text { Masters/Mistress }\end{array}$} \\
\hline $\begin{array}{c}\text { Existence of Specific SBA } \\
\text { procedures at school }\end{array}$ & $\mathrm{F}$ & $\%$ & $\mathrm{~F}$ & $\%$ & $\mathrm{~F}$ & $\%$ \\
\hline Yes & 19 & 54.3 & 155 & 91.2 & 4 & 11.4 \\
\hline No & 16 & 45.7 & 15 & 8.8 & 31 & 88.6 \\
\hline
\end{tabular}

Table 1: Existence of Specific Procedures for Developing SBA Tasks in Secondary Schools by Head Masters/Mistresses (N=35), Science Teachers (N=170) and Academic Masters/Mistresses (N=35) Source: Field Data, (2021)

Responses in table 1 indicate that $54.3 \%$ of the head masters/mistresses confirmed that procedures for developing SBA tasks existed in their schools whereas $45.7 \%$ denied the existence of the procedures. Besides, most of the science teachers designated by $91.2 \%$ those procedures for developing SBA tasks exist in their school, whereas only $8.8 \%$ on the science teachers who deprived of the existence of the procedures. The data also shows that academic masters/mistresses denied the existence of procedures for developing SBA tasks by $88.6 \%$ while only $11.4 \%$ indicated existence of the procedures in their schools. These findings generally indicate that majority of the head masters/mistresses and science teachers were aware of the adopted procedures for developing SBA tasks in secondary schools. This implies that since science teachers are the pillar in SBA practices, their awareness in adaptation of the procedures for developing SBA tasks is important in order to make SBA practices as formative as possible.

The findings also reveal that majority of the academic masters/mistresses denied the existence of procedures for developing SBA tasks in their secondary school. This implies that academic masters/mistresses who are supervisors of all academic activities do not share the same understanding about procedures for developing and administering SBA tools with science teachers and head masters/mistresses. This indicates that there is a confusion of what were the procedures followed by science teachers in integrating SBA practices in secondary schools. These findings are supported by Friyatmi, Rahmi \& Haryanto (2020) who spotted out that clarity in the procedures for development and handling of SBA tasks is a necessity. It is the academic office that handles all assessment activities in secondary schools including giving directives and regulation pertaining to all sorts of assessments. The fact that head masters/mistresses differ in understanding with their academic masters/mistresses indicated that there could be risks associated with purposes of practicing SBA in secondary schools.

The results of science teachers were further used to test a hypothesis that enquired to find out the whether there was a significant difference between public and private science teachers in in their views towards availability of specific procedures in development of SBA tool. The finding that $91.2 \%$ of the science teachers indicated to have specific procedures for developing SBA tools is still not well informative. There was a need of finding out the differences based on school ownership. To test this hypothesis, data from science teachers were used and a chi-square test was run at $95 \%$ confidence level. Results for this test are summarized in table 2:

- $\mathrm{H}_{0} 1$ : There is no significant difference in proportion towards science teachers views on the availability of specific procedures followed in developing SBA tools in public and private secondary schools in Kilimanjaro region.

\begin{tabular}{|c|c|c|c|c|c|}
\hline & Value & df & $\begin{array}{c}\text { Asymptotic Significance } \\
\text { (2-sided) }\end{array}$ & $\begin{array}{l}\text { Exact Sig. } \\
\text { (2-sided) }\end{array}$ & $\begin{array}{l}\text { Exact Sig. } \\
\text { (1-sided) }\end{array}$ \\
\hline Pearson Chi-Square & $2.160^{\mathrm{a}}$ & 1 & .142 & & \\
\hline Continuity Correction $^{b}$ & 1.319 & 1 & .251 & & \\
\hline Likelihood Ratio & 1.992 & 1 & .158 & & \\
\hline Fisher's Exact Test & & & & .196 & .127 \\
\hline $\begin{array}{c}\text { Linear-by-Linear } \\
\text { Association }\end{array}$ & 2.146 & 1 & .143 & & \\
\hline $\mathrm{N}$ of Valid Cases & 170 & & & & \\
\hline
\end{tabular}

Results of hypothesis testing show that $\mathrm{X}^{2}(1, \mathrm{~N}=170)=2.160$, $\mathrm{P}$-value $=0.196$. Since the $\mathrm{p}$-value is greater than significance level (0.05), the null hypothesis was accepted which state that: There is no significant difference in proportion towards science teachers views on the availability of specific procedures followed in developing SBA tools in public and private secondary schools in Kilimanjaro region. This implies that views of public and private science teachers on availability of specific procedures followed in developing SBA tools are not different. Therefore, level of awareness and understanding of public and private science teachers on the procedures followed in developing SBA tools and tasks were the in secondary schools in Kilimanjaro region. 
In curbing this situation, the researcher also requested head masters/mistresses, science teachers and academic masters/mistresses to identify procedures they followed in their schools when developing and handling SBA tasks. Both respondents were teachers by profession and practiced teaching in secondary schools with varying teaching experiences, hence their views were combined to form a table that gave comprehensive overview over their opinions and perception. Through questionnaires for academic masters/mistresses and science teachers, and interview schedules for head masters/mistresses, only a few respondents mention procedures or steps they followed which were summarized and presented in table 3:

\begin{tabular}{|c|c|c|}
\hline Steps on Implementation of SBA & Frequency & Percentage \\
\hline Preparation of lesson plan and scheme of work & 14 & 5.8 \\
\hline Presence of school quality assurance team & 3 & 1.3 \\
\hline Conducting all school examinations in NECTA format & 10 & 4.2 \\
\hline Individual assessment & 13 & 5.4 \\
\hline Introduction of new program at school & 2 & 0.8 \\
\hline Learning computer programme at school & 10 & 4.2 \\
\hline Specifying level of understanding of contents covered & 7 & 2.9 \\
\hline Making general analysis on examination & 2 & 0.8 \\
\hline Consultation to students & 3 & 1.3 \\
\hline Provision of enough practices & 5 & 2.1 \\
\hline Administering the internal examinations & 5 & 2.1 \\
\hline Providing feedback to students after evaluation & 5 & 2.1 \\
\hline $\begin{array}{l}\text { xiii) Ensuring availability of enough learning and teaching } \\
\text { materials }\end{array}$ & 10 & 4.2 \\
\hline xiv) Topics or subtopics covered area of difficulties & 8 & 3.3 \\
\hline
\end{tabular}

Table 3: Procedures or Steps Followed in Developing and Administering SBA Tasks as Mentioned by Head Masters/Mistresses, Science Teachers and Academic Masters/Mistresses (N=240) Source: Field Data, (2021)

Table 3 indicates that out of 240 respondents, only less than $6.0 \%$ could respond to the item that required head masters/mistresses, science teachers and academic masters/mistresses to indicate the procedures they were following to developing SBA tasks in secondary schools. This implies that head masters/mistresses, science teachers and academic masters/mistresses were not sure of the procedures followed in their schools when SBA tasks were developed. This finding coincides with Jonglai, (2017) who contended that teachers normally use their pedagogical knowledge and beliefs to prepare SBAs, procedures that cannot easily be interpreted. This infers that science teachers, academic masters/mistresses and headmasters/mistresses failed to interpret procedures they were following to develop and administer SBA tasks in secondary schools.

Nevertheless, data obtained in table 3 suggested that respondents had no hints about what to consider in developing SBA tasks. All that were mentioned by the respondents have nothing to do with procedures used in development and administration on SBA tools and students' tasks in secondary schools. The finding shows quite clearly that head masters/mistresses, academic masters/mistresses and science teachers had no clue on procedures necessary to be followed in development of SBA tools. Most of the mentioned themes indicated certain facts that are considered essential in development of SBA tasks like tests, assignments, students' presentations, quizzes etc. These facts are well examined by Wiliam\& Thompson (2007) who tried to explain SBA tasks could be made formative and enhance students' involvement. This finding implies that respondents were vibrant about SBA tasks but were not in position to explain the appropriate procedures or necessary steps they followed to develop SBA tasks.

In connection to that, the researcher went on and exposed science teachers to statements that lead to some procedures that could be used to develop and administer SBA tasks in secondary schools. The study was also required to find out whether knowingly or unknowingly science teachers follow procedures in developing SBA tasks and their level of agreeing or disagreeing with those procedures. The intention was to determine the position of science teachers in development of the SBA tasks and quality of the procedures deployed since it can affect the purposes of SBA practices in secondary schools. Science teachers' responses on this question are summarized in Table 4: 


\begin{tabular}{|c|c|c|c|c|c|c|c|c|c|c|c|}
\hline \multirow[b]{2}{*}{ Statements } & \multicolumn{2}{|c|}{$\begin{array}{c}\text { Strong } \\
\text { Disagree }\end{array}$} & \multicolumn{2}{|c|}{ Disagree } & \multicolumn{2}{|c|}{ Undecided } & \multicolumn{2}{|c|}{ Agree } & \multicolumn{2}{|c|}{$\begin{array}{c}\text { Strong } \\
\text { Agree }\end{array}$} & \multirow[t]{2}{*}{ Mean } \\
\hline & $\mathbf{F}$ & $\%$ & $\mathbf{F}$ & $\%$ & $\mathbf{F}$ & $\%$ & $\mathbf{F}$ & $\%$ & $\mathbf{F}$ & $\%$ & \\
\hline $\begin{array}{l}\text { i) I state the purpose or } \\
\text { intention of SBA before preparing } \\
\text { it }\end{array}$ & 3 & 1.8 & 9 & 5.3 & 2 & 1.2 & 121 & 71.6 & 34 & 20.1 & 4.03 \\
\hline $\begin{array}{l}\text { ii) I select resources for SBA } \\
\text { based on the purpose of the } \\
\text { practices }\end{array}$ & 0 & 0.0 & 3 & 1.8 & 4 & 2.4 & 124 & 73.4 & 38 & 22.5 & 4.17 \\
\hline $\begin{array}{l}\text { Iii) I plan for SBA in advance } \\
\text { of the lesson or teaching the } \\
\text { content }\end{array}$ & 0 & 0.0 & 16 & 9.7 & 3 & 1.8 & 112 & 67.9 & 34 & 20.6 & 3.99 \\
\hline $\begin{array}{l}\text { iv) I am competent enough } \\
\text { in developing SBA tools or } \\
\text { instruments }\end{array}$ & 0 & 0.0 & 3 & 1.8 & 15 & 8.9 & 119 & 70.4 & 32 & 18.9 & 4.07 \\
\hline $\begin{array}{l}\text { v) Members in my subject } \\
\text { department check and moderate } \\
\text { my SBA tools } \\
\text { administration }\end{array}$ & 0 & 0.0 & 17 & 10.1 & 15 & 8.9 & 68 & 40.2 & 69 & 40.8 & 4.12 \\
\hline $\begin{array}{llr}\text { vi) I am } & \text { knowledgeable } \\
\text { enough to administer various } \\
\text { types of } \\
\text { assessments }\end{array}$ & 0 & 0.0 & 22 & 13.0 & 16 & 9.5 & 66 & 39.1 & 65 & 38.5 & 4.03 \\
\hline $\begin{array}{l}\text { vii) I am capable of scoring } \\
\text { /marking all school-based } \\
\text { assessments in time }\end{array}$ & 1 & 0.6 & 21 & 12.4 & 3 & 1.8 & 82 & 48.5 & 62 & 36.7 & 4.08 \\
\hline
\end{tabular}

Table 4: Science Teachers' Responses on Procedures Followed in Developing SBA Tasks (n=170)

Source: Field data, (2021)

According to table 4, majority of the science teachers (40.8\%) strongly agree that they give their SBA tasks or tools to members in the subject department for check-up and moderation before administration. Also $38.5 \%$ of the science teachers strongly agree that they are knowledgeable enough to administer various types of SBA practices in secondary schools whereas $36.7 \%$ strongly agree that they are capable of scoring or marking all SBAs in time. Science teachers agreed that they state purposes for SBA, select resources for SBA based on the purpose and that they are competent enough to develop SBA tools or tasks by $71.6 \%, 73.4 \%$ and $70.4 \%$ respectively. These data indicate that almost all science teachers agree or strongly agree with the statements on adopting procedures for developing SBA tasks. This finding implies that science teachers follow certain procedures in developing SBA tasks but probably those procedures may not be so obvious for science teachers to identify them.

As opposed to that, there are degrees of disagreement among science teachers, most especially on knowledge of administering SBA instruments (13.0\%) and capabilities of teachers to score all SBAs in time (12.4\%). Disagreement was also indicated in all other aspects like departmental moderation (10.1\%), planning in advance (9.7\%), statement of purposes (5.3\%) while selecting resources and competency in developing SBA tools were $1.8 \%$. These findings confirm that some science teachers do not follow procedures when developing SBA tasks. This implies that either science teachers neglected the procedures for developing SBA tasks or the procedures were not in place or enforced in secondary schools. This finding conflicts with Maile, (2013) who spotted out that for SBA tasks may only be formative if they follow important procedures, otherwise they are just administered for non-formative purposes. Therefore, some science teachers proved to have developed and administered SBA tasks in a custom that violets evidence of formativity of science students.

The researcher also intended to confirm whether the levels of agreement and disagreement were confined to science teachers' years of teaching experience. To test the hypothesis, one way ANOVA was run at 95\% confidence level. ANOVA was suitable for this aspect since there were four groups of years of experience to compare and the dependent variable was agreement mean scores. The results of hypothesis testing are summarized on table 5:

- Ho2: There is no significant agreement mean score difference on the procedures followed in developing SBA tools between categories of years of teaching experience of science teachers in secondary schools in Kilimanjaro region.

\begin{tabular}{|c|c|c|c|c|c|}
\hline & Sum of Squares & df & Mean Square & F & Sig. \\
\hline Between Groups & 2.467 & 3 & .822 & 3.162 & .026 \\
\hline Within Groups & 41.878 & 161 & .260 & & \\
\hline Total & 44.345 & 164 & & & \\
\hline
\end{tabular}

Table 5: ANOVA Summary Table for $\mathrm{H}_{0} 2$

Source: Field data, (2021)

Results of hypothesis testing show that $\mathrm{F}(3,161)=3.162$ and P-value $=0.026$. Since the p-value $(0.026)$ is less than the significance level (0.05) the null hypothesis is rejected and accept the alternative hypothesis which states: There 
is significant agreement mean score difference on the procedures followed in developing SBA tools between categories of years of teaching experience of science teachers in secondary schools in Kilimanjaro region. This indicates that the four categories of years of experience do affect the agreement scores on the procedures followed by science teachers in order to develop SBA practices at almost different rates. To make the findings more interpretable, the descriptive statistics of the one-way ANOVA analysis was summarized in table 6:

\begin{tabular}{|c|c|c|c|c|c|c|c|}
\hline & \multirow[t]{2}{*}{$\mathbf{N}$} & \multirow[t]{2}{*}{ Mean } & \multirow[t]{2}{*}{$\begin{array}{c}\text { Std. } \\
\text { Deviation }\end{array}$} & \multirow[t]{2}{*}{$\begin{array}{l}\text { Std. } \\
\text { Error }\end{array}$} & \multicolumn{2}{|c|}{$\begin{array}{c}\text { 95\% Confidence Interval for } \\
\text { Mean }\end{array}$} \\
\hline & & & & & & $\begin{array}{l}\text { Lower } \\
\text { Bound }\end{array}$ & $\begin{array}{l}\text { Upper } \\
\text { Bound }\end{array}$ \\
\hline \multicolumn{2}{|c|}{$0-5$ years } & 38 & 4.1316 & .46426 & .07531 & 3.9790 & 4.2842 \\
\hline \multicolumn{2}{|c|}{$6-10$ years } & 53 & 3.9461 & .66135 & .09084 & 3.7638 & 4.1284 \\
\hline \multicolumn{2}{|c|}{$11-15$ years } & 23 & 3.9627 & .46832 & .09765 & 3.7602 & 4.1653 \\
\hline \multicolumn{2}{|c|}{ 16years and above } & 51 & 4.2269 & .35591 & .04984 & 4.1268 & 4.3270 \\
\hline \multicolumn{2}{|l|}{ Total } & 165 & 4.0779 & .52000 & .04048 & 3.9980 & 4.1579 \\
\hline \multirow[t]{2}{*}{ Model } & Fixed Effects & & & .51001 & .03970 & 3.9995 & 4.1563 \\
\hline & Random Effects & & & & .07336 & 3.8445 & 4.3114 \\
\hline
\end{tabular}

Table 6: Descriptive Table for one-way ANOVA Source: Field data, (2021)

The descriptive analysis table 6 indicates that the category of 16 years and above has the highest mean of 4.2269 as compared to other age categories. This implies that the long-experienced teachers got involved in SBA practices for many years since its inception and hence rated the concepts on procedures for developing SBA tools higher. Science teachers of this age category might have had attended many in-service trainings and therefore skilled in following procedures during development of SBA tools which are formative by nature. The less experienced age category of 0 to 5 years teaching experience is indicated have the second highest mean of 4.1316. This is the youngest group of science teachers which is energetic enough to practice SBA in secondary schools. The category could have been still practicing what they got from colleges and universities, had the zeal for trying new things they learn from their senior science teachers they find in places of work in their process of learning about what works well in SBA practices. Consequently, the two groups with high mean influenced the agreement mean scores significant differences among the age categories.

The researcher then asked the same question to academic masters/mistresses to check if there is a difference in their responses on how science teachers follow procedures in developing and implementing SBA tasks in secondary schools. It was important to inquire science teachers' information from academic masters/mistresses since they are the immediate supervisors and overseer of all assessment practices in secondary schools, Table 7 shows their responses on the item:

\begin{tabular}{|c|c|c|c|c|c|c|c|c|c|c|c|}
\hline \multirow[t]{2}{*}{ Statements } & \multicolumn{2}{|c|}{$\begin{array}{l}\text { Strongly } \\
\text { Disagree }\end{array}$} & \multicolumn{2}{|c|}{ Disagree } & \multicolumn{2}{|c|}{ Undecided } & \multicolumn{2}{|c|}{ Agree } & \multicolumn{2}{|c|}{$\begin{array}{c}\text { Strongly } \\
\text { Agree }\end{array}$} & \multirow[t]{2}{*}{ Mean } \\
\hline & $\mathbf{F}$ & $\%$ & $\mathbf{F}$ & $\%$ & $\mathbf{F}$ & $\%$ & $\mathbf{F}$ & $\%$ & $\mathbf{F}$ & $\%$ & \\
\hline $\begin{array}{l}\text { i) Science teachers state the } \\
\text { purpose or intention of SBA before } \\
\text { preparing it }\end{array}$ & 0 & 0.0 & 0 & 0.0 & 1 & 2.9 & 21 & 60.0 & 13 & 37.1 & 4.34 \\
\hline $\begin{array}{l}\text { ii) Science teachers select } \\
\text { resources for SBA based on the } \\
\text { purpose of the practices }\end{array}$ & 0 & 0.0 & 0 & 0.0 & 0 & 0.0 & 16 & 45.7 & 19 & 54.3 & 4.54 \\
\hline $\begin{array}{l}\text { Science teachers plan for SBA } \\
\text { in advance of the lessons or teaching } \\
\text { the content }\end{array}$ & 0 & 0.0 & 0 & 0.0 & 1 & 2.9 & 15 & 42.9 & 19 & 54.3 & 4.51 \\
\hline $\begin{array}{l}\text { iv) Science teachers are } \\
\text { competent enough in developing SBA } \\
\text { tools or instruments }\end{array}$ & 0 & 0.0 & 0 & 0.0 & 1 & 2.9 & 20 & 57.1 & 14 & 40.0 & 4.37 \\
\hline $\begin{array}{l}\text { v) Members in subject } \\
\text { departments check and moderate SBA } \\
\text { tools or tasks before administration }\end{array}$ & 0 & 0.0 & 0 & 0.0 & 3 & 8.6 & 24 & 68.6 & 8 & 22.9 & 4.14 \\
\hline $\begin{array}{l}\text { vi) Science teachers are } \\
\text { knowledgeable enough to administer } \\
\text { various types of school-based } \\
\text { assessments }\end{array}$ & 0 & 0.0 & 0 & 0.0 & 1 & 2.9 & 10 & 28.6 & 24 & 68.6 & 4.66 \\
\hline $\begin{array}{l}\text { vii) Science teachers are capable } \\
\text { of scoring /marking all school-based } \\
\text { assessments in time }\end{array}$ & 0 & 0.0 & 1 & 2.9 & 0 & 0.0 & 16 & 45.7 & 18 & 51.4 & 4.46 \\
\hline
\end{tabular}

Table 7: Academic Masters/Mistresses Response on Procedures Followed by Science Teacher in Developing and Administering SBA Tasks (N=35)

Source: Field Data, (2021) 
Information obtained from academic masters/mistresses and summarized in table 7 designates that all respondents agreed and strongly agreed by over $90.0 \%$ with all of procedures followed by science teachers in developing SBA tasks. This finding establishes existence of certain procedures in secondary schools that science teachers followed when developing SBA tasks or tools. The finding suggests that academic masters/mistresses are to a greater extent backing up the findings obtained from science teachers that indicated to have followed procedures in developing and administering SBA tasks in teaching of science subjects in secondary schools in Kilimanjaro region. In certainty the finding infers that academic masters/mistress have the same understanding as that of science teachers regarding procedures for developing SBA tasks since it is evinced that these results support what was found out from science teachers.

The table also indicated small proportions of academic masters/mistresses to neither agree nor disagree on the procedures used by science teachers in developing SBA tasks. This shows that some academic masters were not in position to approve or disapprove procedures that science teachers used to develop SBA tasks in secondary schools. This may imply that some academic masters/mistresses are not aware of the procedures and they are unwilling to learn from what their subordinate science teachers practice in developing their SBA tasks for students. It may also imply that some science teachers do not follow procedures for developing SBA tasks eagerly but reluctantly, while the academic masters/mistresses could have stemmed the problem by being uninformed about procedures for developing SBA tasks. On the other hand, head masters/mistresses were required to rate performance of science teachers based on the procedures they were following in developing and administering SBA tasks in secondary schools in Kilimanjaro region.

The aim of capturing these responses was to find out the extent to which school administration embraces the process of developing SBA tasks since it has a significant effect on the outcome of SBA practices in secondary school teaching and learning. The rating of head masters/mistresses' responses were summarized in table 8:

\begin{tabular}{|c|c|c|c|c|c|c|c|c|c|c|c|}
\hline \multirow[b]{2}{*}{ Procedures } & \multicolumn{2}{|c|}{ Very poor } & \multicolumn{2}{|c|}{ Poor } & \multicolumn{2}{|c|}{ Fair } & \multicolumn{2}{|c|}{ Good } & \multicolumn{2}{|c|}{ Excellent } & \multirow[t]{2}{*}{ Mean } \\
\hline & $\mathbf{F}$ & $\%$ & $\mathbf{F}$ & $\%$ & $\mathbf{F}$ & $\%$ & $\mathbf{F}$ & $\%$ & $\mathbf{F}$ & $\%$ & \\
\hline $\begin{array}{l}\text { Science teachers state the purpose or intention } \\
\text { of SBA before preparing it }\end{array}$ & 0 & 0.0 & 0 & 0.0 & 5 & 15.2 & 22 & 66.7 & 6 & 18.2 & 4.03 \\
\hline $\begin{array}{l}\text { Science teachers select resources for SBA } \\
\text { based on the purpose of the practices }\end{array}$ & 0 & 0.0 & 2 & 5.7 & 6 & 17.1 & 10 & 28.6 & 17 & 48.6 & 4.20 \\
\hline $\begin{array}{l}\text { Science teachers plan for SBA in advance of the } \\
\text { lessons or teaching the content }\end{array}$ & 0 & 0.0 & 0 & 0.0 & 6 & 18.8 & 16 & 50.0 & 10 & 31.2 & 4.13 \\
\hline $\begin{array}{l}\text { Science teachers are competent enough in } \\
\text { developing SBA tools or instruments }\end{array}$ & 0 & 0.0 & 0 & 0.0 & 6 & 17.1 & 17 & 48.6 & 12 & 34.3 & 4.17 \\
\hline $\begin{array}{l}\text { v) Members in subject departments check and } \\
\text { moderate SBA tools or tasks before administration }\end{array}$ & 0 & 0.0 & 2 & 5.7 & 6 & 17.1 & 15 & 42.9 & 12 & 34.3 & 4.06 \\
\hline $\begin{array}{l}\text { vi) Science teachers are knowledgeable enough to } \\
\text { administer various types of school-based assessments }\end{array}$ & 0 & 0.0 & 0 & 0.0 & 6 & 17.1 & 15 & 42.9 & 14 & 40.0 & 4.23 \\
\hline $\begin{array}{l}\text { vii) Science teachers are capable of scoring } \\
\text { /marking all school-based assessments in time }\end{array}$ & 0 & 0.0 & 2 & 5.7 & 6 & 17.1 & 19 & 54.3 & 8 & 22.9 & 3.94 \\
\hline
\end{tabular}

Table 8: Head Masters/Mistresses Rating on Procedures Followed by Science Teachers in Developing and Administering SBA Tasks (N=35)

Source: Field Data, (2021)

The information in table 8 shows that, except for ability of teachers to select SBA resources which was rated excellent by $48.6 \%$ by the head masters/mistresses, while the rest of the procedures followed by science teachers in developing SBA tasks were rated excellent by less than $40.0 \%$ of the respondents. to range from good to poor. This finding indicates that most of the head masters/mistresses are not to a high extent contented by the modality adopted by science teachers processing SBA tasks in secondary schools in Kilimanjaro region. The finding suggests that there was still room for improving the procedures and make them obvious and easy to be assessed by the school administration.

This outcome was also suggested by one of the DEOs during an interview with the DEO of district 'E' who said:

'Most secondary schools observe specific and timely procedures in preparing CA tests, I think it is also time that we sit down and re-think of best procedures that enhance SBAs instead of just leaving it to the subject teacher. Procedures are important so that at least we develop grounds of holding teachers and students accountable for the practices as opposed to what is happening now in our schools......' (29/04/2021).

Nevertheless, the study found out that majority of the head masters/mistresses opted for the procedures followed by science teachers to develop SBA tasks to be good by over $40.0 \%$. This finding can be interpreted that head masters/mistresses are aware of some procedures that are followed by science teachers in attempting to develop SBA tasks for the students in secondary schools. This implies that although school administrators are not highly excited by the processing of SBA tasks, they are in a way accept the need for such processes as one of the strategies of improving quality of SBA program of science subjects in secondary schools.

This finding complies with Black \&Wiliam, (2010) who insisted that formative assessments are not static but dynamic by nature as subject teachers play a great role of meeting students demands. This implies that students' demands in teaching and learning would always emerge and addressed to by teachers as they are disclosed every not and then through SBA practices. These findings are supported by Poliah, (2010) who stressed that teachers have to be vigilant enough to accommodate new inventions that intent to improve the quality of SBA practices. It is believed that since 2005 when SBA practices had been adopted, some stabilities have been attained to establish proper procedures that can be followed by all science teachers in secondary schools in order to bring harmonization among SBA stakeholders. 
Finally, the researcher captured the responses of science students from various secondary schools in order to establish an aspect of students' involvement in the procedures adopted by science teachers in developing SBA tasks. The aim was to find students consideration by their study subjects in the procedures followed by science teachers. The position of science students in planning of for SBA tasks is very important since this is where assessment formative aspect (AFA) can be determined. Students' responses of the procedure adopted by science teachers in developing SBA tasks were captures and summarized in table 9:

\begin{tabular}{|c|c|c|c|c|c|c|c|c|c|c|c|}
\hline \multirow[b]{2}{*}{ Statements } & \multicolumn{2}{|c|}{ Strong disagree } & \multicolumn{2}{|c|}{ Disagree } & \multicolumn{2}{|c|}{ Undecided } & \multicolumn{2}{|c|}{ Agree } & \multicolumn{2}{|c|}{ Strong agree } & \multirow[t]{2}{*}{ Mean } \\
\hline & $\mathbf{F}$ & $\%$ & $\mathbf{F}$ & $\%$ & $\mathbf{F}$ & $\%$ & $\mathbf{F}$ & $\%$ & $\mathbf{F}$ & $\%$ & \\
\hline \multicolumn{12}{|c|}{ The teacher states the purpose or intention of SBA in advance } \\
\hline Biology & 61 & 9.3 & 92 & 14.1 & 32 & 4.9 & 337 & 51.6 & 131 & 20.1 & 3.59 \\
\hline Chemistry & 46 & 7.2 & 95 & 14.9 & 36 & 5.6 & 308 & 48.3 & 153 & 24.0 & 3.67 \\
\hline Physics & 58 & 9.1 & 123 & 19.4 & 38 & 6.0 & 295 & 46.5 & 121 & 19.1 & 3.47 \\
\hline \multicolumn{12}{|c|}{ The teacher instructs us on how to select resources for SBA preparation } \\
\hline Biology & 10 & 1.5 & 109 & 16.7 & 32 & 4.9 & 328 & 50.4 & 172 & 26.4 & 3.83 \\
\hline Chemistry & 6 & 0.9 & 111 & 17.5 & 38 & 6.0 & 317 & 49.8 & 164 & 25.8 & 3.82 \\
\hline Physics & 27 & 4.2 & 160 & 25.1 & 38 & 6.0 & 258 & 40.4 & 155 & 24.3 & 3.55 \\
\hline \multicolumn{12}{|c|}{ We are always assessed during lessons } \\
\hline Biology & 28 & 4.3 & 71 & 10.9 & 19 & 2.9 & 341 & 52.4 & 192 & 29.5 & 3.92 \\
\hline Chemistry & 22 & 3.4 & 72 & 11.3 & 18 & 2.8 & 325 & 50.9 & 201 & 31.5 & 3.96 \\
\hline Physics & 21 & 3.3 & 94 & 14.8 & 39 & 6.2 & 309 & 48.8 & 170 & 26.9 & 3.81 \\
\hline \multicolumn{12}{|c|}{ We are only assessed after finishing a topic or sub-topic } \\
\hline Biology & 34 & 5.3 & 120 & 18.5 & 11 & 1.7 & 289 & 44.7 & 193 & 29.8 & 3.75 \\
\hline Chemistry & 29 & 4.6 & 132 & 20.9 & 11 & 1.7 & 248 & 39.2 & 213 & 33.6 & 3.76 \\
\hline Physics & 35 & 5.5 & 136 & 21.4 & 11 & 1.7 & 255 & 40.1 & 199 & 31.3 & 3.70 \\
\hline \multicolumn{12}{|c|}{ The teacher marks the assessments on time } \\
\hline Biology & 27 & 4.2 & 155 & 24.0 & 29 & 4.5 & 249 & 38.6 & 185 & 28.7 & 3.64 \\
\hline Chemistry & 29 & 4.6 & 153 & 24.2 & 84 & 13.3 & 207 & 32.7 & 160 & 25.3 & 3.50 \\
\hline Physics & 64 & 10.1 & 189 & 29.9 & 27 & 4.3 & 219 & 34.7 & 133 & 21.0 & 3.27 \\
\hline \multicolumn{12}{|c|}{ The teacher rarely marks the assessments conducted in class } \\
\hline Biology & 31 & 4.8 & 227 & 35.0 & 42 & 6.5 & 263 & 40.5 & 86 & 13.3 & 3.22 \\
\hline Chemistry & 55 & 8.7 & 195 & 30.8 & 43 & 6.8 & 270 & 42.6 & 71 & 11.2 & 3.17 \\
\hline Physics & 51 & 8.0 & 270 & 42.4 & 28 & 4.4 & 202 & 31.7 & 86 & 13.5 & 3.00 \\
\hline \multicolumn{12}{|c|}{ I like the assessment practices in school } \\
\hline Biology & 6 & 0.9 & 50 & 7.7 & 29 & 4.5 & 292 & 44.9 & 273 & 42.0 & 4.19 \\
\hline Chemistry & 21 & 3.3 & 2 & 0.3 & 35 & 5.5 & 275 & 43.1 & 305 & 47.8 & 4.32 \\
\hline Physics & 50 & 7.9 & 10 & 1.6 & 33 & 5.2 & 294 & 46.4 & 247 & 39.0 & 4.07 \\
\hline \multicolumn{12}{|c|}{ Assessments during the lesson help us to learn more } \\
\hline Biology & 24 & 3.7 & 5 & 0.8 & 39 & 6.0 & 272 & 42.0 & 308 & 47.5 & 4.29 \\
\hline Chemistry & 10 & 1.6 & 2 & 0.3 & 37 & 5.8 & 258 & 40.4 & 331 & 51.9 & 4.41 \\
\hline Physics & 20 & 3.1 & 6 & 0.9 & 35 & 5.5 & 260 & 40.9 & 315 & 49.5 & 4.33 \\
\hline
\end{tabular}

Table 9: Students Responses on Procedures Adopted by Science Teachers in Developing and Administering SBA Tasks ( $n=665)$

Source: Field data, (2021)

Students' data that were gathered through questionnaires indicate that respondents strongly agreed to like assessment practices and SBA conducted during lessons help them to learn more by over $40.0 \%$. These findings imply that science students for all subjects that participated in this study were highly excited by SBA practices since it is of good help to them when conducted on time during the learning of topics or subtopics. This finding is the core focus of introduction of SBA practices in secondary schools as narrated by Mkpae (2017) that in Nigeria, when SBA practices were used formatively, high students interests, good performance and high skill development were testified.

On the other hand, majority of the students agreed by over $40.0 \%$ that they were assessed by science teachers after finishing a topic or sub-topic. Almost the same percentage of students reported science teachers to have rarely marked assessments conducted in class. These two findings contradict the findings obtained from science teachers which indicated that they administered SBA tasks while teaching topics or sub-topics and mark all students' SBA tasks on time. The inconsistency implies that there is a discrepancy in the procedures that are adopted by science teachers in developing and administering SBA tasks in secondary schools in Kilimanjaro region. This outcome is supported by information obtained through document analysis that teachers indicated to provide assignments to students but student books went unmarked, on the assumption that the teachers provided solution to the whole class.

When zonal quality assurers were probed during an in-depth interview about incidences where students book went unmarked, one of the zonal school quality assurers'YQ' explained:

'Yes, we have a criterion of checking students' books both lesson notes and assessment books where they are used separately. We hardly spend three days in a school and some schools are very big, with many teachers and many students. So, you see, it is not very easy do notice that the unmarked assignments were handled effectively during the lesson........... but subject teachers have various ways of handling their classes, most especially the challenging ones with many students seated in one room and the like.....'(17/05/2021). 
However, a good number of students were reported in table 9 to have not decided, disagreed and strongly disagreed on several facts about procedures followed by science teachers in developing and administering of SBA tasks in secondary schools. The findings cramped to the incorrect ideas of Olufunmilayo et al, (2016) who assumed that procedures followed in preparing SBA tasks ought to merely be linear steps provides no room for a constructive dialogue between the teachers, instructional materials and the learners. This implies that the discrepancies that emerged from science teachers and students concerns requires an intervention of establishing appropriate procedures for developing and administering SBA tasks in secondary schools.

\section{Science Teachers' Skills on Procedures and Techniques for Preparing SBA Tasks}

This second section of the second research question was designed to rate the extent to which science teachers were equipped with skills on the techniques and procedures used or adopted in order to develop and administer SBA tasks in secondary schools. Information to address this question was attained from science teachers, head masters/mistresses, DEOs and ZQA. The researcher begun by inquiring science teachers to indicate (through an agreement rating scale) the extent to which they are equipped with skills on handling the techniques and procedures that were adopted and followed in development and administration of SBA tasks in their schools. Results are presented and described first then followed by supportive results from head masters/mistresses who in this case were their immediate administrators. Table 10 presents responses from science teachers on their skills possession about the techniques and procedures for developing SBA tasks in secondary schools.

\begin{tabular}{|c|c|c|c|c|c|c|c|c|c|c|c|}
\hline \multirow{2}{*}{ Statements } & \multicolumn{2}{|c|}{ Not at all } & \multicolumn{2}{|c|}{$\begin{array}{c}\text { To Small } \\
\text { Extent }\end{array}$} & \multicolumn{2}{|c|}{$\begin{array}{c}\text { To a Moderate } \\
\text { Extent }\end{array}$} & \multicolumn{2}{|c|}{$\begin{array}{c}\text { To a Greater } \\
\text { Extent }\end{array}$} & \multicolumn{2}{|c|}{$\begin{array}{c}\text { To a Very } \\
\text { Greater Extent }\end{array}$} & \multirow[t]{2}{*}{ Mean } \\
\hline & $\mathbf{F}$ & $\%$ & $\mathbf{F}$ & $\%$ & $\mathbf{F}$ & $\%$ & $\mathbf{F}$ & $\%$ & $\mathbf{F}$ & $\%$ & \\
\hline $\begin{array}{ll}\text { i) } & \text { I have learned useful } \\
\text { SBA procedures and } \\
\text { techniques through colleagues }\end{array}$ & 18 & 10.7 & 11 & 6.5 & 36 & 21.4 & 64 & 38.1 & 39 & 23.2 & 3.57 \\
\hline $\begin{array}{l}\text { Ii) I have learned useful } \\
\text { SBA procedures and } \\
\text { techniques through trial and } \\
\text { error }\end{array}$ & 33 & 19.6 & 12 & 7.1 & 65 & 38.7 & 29 & 17.3 & 29 & 17.3 & 3.05 \\
\hline $\begin{array}{l}\text { iii) I have attended a } \\
\text { good number of seminars on } \\
\text { SBA procedures and } \\
\text { techniques }\end{array}$ & 49 & 29.2 & 44 & 26.2 & 22 & 13.1 & 34 & 20.2 & 19 & 11.3 & 2.58 \\
\hline $\begin{array}{l}\text { iv) The school always } \\
\text { conduct seminars on SBA } \\
\text { procedures and techniques }\end{array}$ & 60 & 35.7 & 48 & 28.6 & 38 & 22.6 & 8 & 4.8 & 14 & 8.3 & 2.21 \\
\hline $\begin{array}{l}\text { v) Quality assurers } \\
\text { always insist on proper use of } \\
\text { SBA procedures and } \\
\text { techniques }\end{array}$ & 36 & 21.4 & 13 & 7.7 & 41 & 24.4 & 57 & 33.9 & 21 & 12.5 & 3.08 \\
\hline $\begin{array}{l}\text { vi) The knowledge I have } \\
\text { on SBA procedures and } \\
\text { techniques is enough to make } \\
\text { me a good assessor }\end{array}$ & 30 & 17.9 & 13 & 7.7 & 51 & 30.4 & 53 & 31.5 & 21 & 12.5 & 3.13 \\
\hline $\begin{array}{l}\text { vii) I still need more } \\
\text { training on SBA procedures } \\
\text { and techniques }\end{array}$ & 3 & 1.8 & 52 & 31.0 & 17 & 10.1 & 38 & 22.6 & 58 & 34.5 & 3.57 \\
\hline $\begin{array}{l}\text { viii) I am capable of } \\
\text { setting SBA tools or } \\
\text { instruments without assistance } \\
\text { from my colleagues }\end{array}$ & 8 & 4.8 & 36 & 21.4 & 32 & 19.0 & 72 & 42.9 & 20 & 11.9 & 3.36 \\
\hline
\end{tabular}

Table 10: Skills Possessed by Science Teachers on the Techniques and Procedures Followed in Developing and Administering SBA Tasks ( $N=170)$

Source: Field Data, (2021)

The summarized information in table 10 indicates that $34.8 \%$ (which is the highest) of the science teachers still need more training on SBA procedures and techniques to a very greater extent. This finding could be interpreted that science teachers have confirmed existence of a well-known discrepancy or weakness in SBA practices in secondary schools in Kilimanjaro region. The finding infers that science teachers are aware of the usefulness of the appropriate procedures and techniques but they find it difficult to associate SBA tasks with the happenings in secondary schools, and thus have indicated that they need more of trainings on SBA practices. This finding is supported by Jonglai, (2017) whose study indicated that there could be many contextual factors affecting SBA implementation process which can in turn make the SBA practices deviated from the objectives. In those regards then, science teachers rose a concern that can only be handled through SBA trainings.

Through table 10 again science teachers indicated to have learned useful SBA procedures and techniques from colleges and universities (38.1\%) and so they were capable of setting SBA tasks without assistance from colleagues $(42.9 \%)$ to a greater extent. This rating of science teachers was probably attributed to proper training of science teachers 
from teachers' colleges and universities. It implies that science teachers acknowledge SBA skills on the procedures and techniques that they acquired from various colleges and universities probably in Tanzania or outside. The study by Nair et al., (2014) pointed out that, although trained teachers have some degrees of satisfaction in conducting SBA practices, they still face couple of challenges of which among others was identification of the right procedures and techniques of developing SBA formatively. This is the case with science teachers who are confirmed to graduate from colleges but with limited skills on the procedures and techniques for handling SBA tasks formatively.

On the other hand, $33.9 \%$ of the science teachers indicated that quality assurers always insisted them on proper use of SBA procedures and techniques to a greater extent whereas $21.4 \%$ of the same respondents declined the statement at all. This is a very alerting finding since the opinions were obtained from the same group of respondents. This implies that probably quality assurers gave less weight on the procedures and techniques followed by science teacher in developing and administering of SBA tasks. It may also imply that quality assurers do not go deeper enough during their visits to the schools, most especially quality assurers who are specialized in science subjects. This finding corresponds with field visit where it was confirmed that there were only 7 zonal school quality assurers who were mandated to ensure quality of science teaching of Kilimanjaro and Tanga regions, of which Kilimanjaro region alone had 346 secondary schools.

The finding was also supported by one of the zonal school quality assurers, 'QY' who remarked during an interview that:

'We are all together very few such that it is even very difficult to sometimes visit all secondary schools twice in a year. Like for science subjects, we are very few and according to our standards, arts teachers can't be sent to observe and ensure quality of science subjects. We normally go for school visits as team with mixed subject combinations so that we do not miss some aspects of quality as a team, but it comes to some points where you need certain combinations in the team and find it is not possible because of subject combination, mostly science combinations are scarce here' (18/5/2021).

Nevertheless, science teachers as indicated in table 10 mentioned to have attended seminars and schools always conduct seminars to small extent by $26.2 \%$ and $28.6 \%$ respectively, whereas the same respondents indicated to not to do so at all by $29.2 \%$ and $35.7 \%$ respectively. These findings show that there were no trainings going on to improve quality of science teachers based on inculcating them with skills on procedures and techniques for developing and administering of SBA tasks in secondary schools in Kilimanjaro region. Higher numbers of science teachers who had never attended seminars at all and schools had never conducted seminars on SBA practices could be emergent new culture in science teaching found in secondary schools. The study by O'Malley et al., (2019) emphasized administrators to get rid of such bad emergent culture in SBA practices before it becomes a habit. This implies that science teachers were ready to attend seminars that can improve their SBA practices.

In triangulating information from science teachers, head masters/mistresses were also asked to indicate the extent to which science teachers were equipped with skills on SBA procedures and techniques. It was important to get views from head masters/mistresses since they are the ones responsible for teachers' career development in secondary schools. Their responses on this question are summarized in table 11:

\begin{tabular}{|c|c|c|c|c|c|c|c|c|c|c|c|}
\hline \multirow[t]{2}{*}{ Statements } & \multicolumn{2}{|c|}{$\begin{array}{c}\text { Not At } \\
\text { All }\end{array}$} & \multicolumn{2}{|c|}{$\begin{array}{l}\text { To Small } \\
\text { Extent }\end{array}$} & \multicolumn{2}{|c|}{$\begin{array}{c}\text { To a } \\
\text { Moderate } \\
\text { Extent }\end{array}$} & \multicolumn{2}{|c|}{$\begin{array}{l}\text { To a } \\
\text { Greater } \\
\text { Extent }\end{array}$} & \multicolumn{2}{|c|}{$\begin{array}{l}\text { To A Very } \\
\text { Greater } \\
\text { Extent }\end{array}$} & \multirow[t]{2}{*}{ Mean } \\
\hline & $\mathbf{F}$ & $\%$ & $\mathbf{F}$ & $\%$ & $\mathbf{F}$ & $\%$ & $\mathbf{F}$ & $\%$ & $\mathbf{F}$ & $\%$ & \\
\hline $\begin{array}{l}\text { i) Science teachers learned useful SBA } \\
\text { procedures and techniques through } \\
\text { colleagues }\end{array}$ & 0 & 0.0 & 0 & 0.0 & 9 & 25.7 & 18 & 51.4 & 8 & 22.9 & 3.97 \\
\hline $\begin{array}{l}\text { Science teachers learned useful SBA } \\
\text { procedures and techniques through trial and } \\
\text { error }\end{array}$ & 7 & 20.0 & 4 & 11.4 & 8 & 22.9 & 10 & 28.6 & 6 & 17.1 & 3.11 \\
\hline $\begin{array}{l}\text { iii) Science teachers have attended a } \\
\text { good number of seminars on SBA procedures } \\
\text { and techniques }\end{array}$ & 0 & 0.0 & 9 & 25.7 & 4 & 11.4 & 15 & 42.9 & 7 & 20.0 & 3.57 \\
\hline $\begin{array}{l}\text { iv) The school always conducts } \\
\text { seminars on SBA procedures and techniques }\end{array}$ & 3 & 8.6 & 11 & 31.4 & 4 & 11.4 & 16 & 45.7 & 1 & 2.9 & 3.03 \\
\hline $\begin{array}{l}\text { v) Quality assurers always conducts } \\
\text { seminars on SBA procedures and techniques }\end{array}$ & 0 & 0.0 & 2 & 5.7 & 9 & 25.7 & 15 & 42.9 & 9 & 25.7 & 3.89 \\
\hline $\begin{array}{l}\text { vi) The knowledge science teachers } \\
\text { have on SBA procedures and techniques }\end{array}$ & 0 & 0.0 & 0 & 0.0 & 13 & 37.1 & 14 & 40.0 & 8 & 22.9 & 3.86 \\
\hline $\begin{array}{l}\text { vii) Science teachers still need more } \\
\text { training on SBA procedures and techniques }\end{array}$ & 0 & 0.0 & 0 & 0.0 & 3 & 8.6 & 21 & 60.0 & 11 & 31.4 & 4.23 \\
\hline $\begin{array}{l}\text { viii) Science teachers are capable of } \\
\text { setting SBA tools or instruments or tasks } \\
\text { without assistance from colleagues }\end{array}$ & 0 & 0.0 & 0 & 0.0 & 9 & 25.7 & 22 & 62.9 & 4 & 11.4 & 3.86 \\
\hline
\end{tabular}

Table 11: Head Masters/mistresses Rating on the Extent of Skills Possessed by Science Teachers on the Techniques and Procedures Followed in Developing and Administering SBA Tasks $(n=35)$

Source: Field data, (2021)

According to data in table 11 majority (over 40\%) of the head masters/mistresses indicated science teachers to possess the required skills and techniques in developing and administering SBA tasks to a greater extent while a few 
indicated to a very greater extent. This finding concurs with what science teachers rated themselves, only that head masters/mistresses rated a bit high. This finding implies that head masters/mistresses work closely with science teachers to the level of realizing their capabilities and weaknesses in developing and administering SBA tasks. Despite the fact that not all head masters/mistresses were science teachers by profession, they were able to understand and contemplate the position of science teachers in developing SBA tasks which portray a great administrative quality.

As it is also indicated in the table 11, only a few headmasters spotted that science teachers to not at all learn useful SBA procedures and techniques through trial and error (20.0\%) whereas presence of seminars on SBA procedures and techniques received the same remarks by $8.6 \%$. These findings are not different from what was indicated by science teachers, which implies that head masters/mistresses and science teachers were in one accord, working closely and share the gains and losses together. These findings differ from those of Fulmer et al., (2017) who pointed out that teachers and head of schools were against each other in rating policies, school man agents and perspectives of assessments at school. These findings are in line with the findings obtained during the interviews. For example, one DEO from district ' $\mathrm{C}$ ' said; 'Heads of schools and science teachers, even laboratory technicians should work as a team, should speak one language and listen to one another, since this is the only way, they can afford teaching of science subjects' (03/05/2021).

In response to the same matter in an interview, another DEO of district ' $A$ ' reported;

'Assessment is a collaborative work, it highly demands every member in the department to actively get involved starting from development of instruments to marking of the tests, even discussion of students' progress. So, head master or head mistress, the academic office, discipline teachers and the subject teachers must work together as a team, we emphasize team work, that's all. Short of that its chaotic, you will only hear noises of complaining from all over in the school' $(20 / 05 / 2021)$.

Therefore, both head masters/mistresses and science teachers could work openly and collaboratively in adopting procedures and techniques for developing and administering SBA tasks in secondary schools in Kilimanjaro region. The finding also infers those procedures for certain specific assessments are well established and followed by all secondary schools, but procedures for developing and administering SBA tasks are not well established in most secondary schools. This observation gives notions that each school has own ways of establishing SBA practices, an exercise that was just adopted, therefore procedures and techniques for developing and administering SBA tasks were left to emerge and advance for themselves in the school systems as suggested by the complex adaptive system theory (Schneider \& Somers,2006).

\section{Conclusions}

Based on the findings, the study concluded that;

There are no specific procedures for developing and implementing SBA tasks that are adopted and followed by science teachers in Kilimanjaro region. The study found out that science teachers have their own ways of developing and administering SBA tasks, that are not even supported by head masters/mistresses and academic masters. This manifestation leaves disagreements across the region that jeopardizes quality of the implementation of SBA practices of science subjects in secondary schools in Kilimanjaro region.

The existing procedures and techniques that were identified to have been followed by science teachers in development and administration of SBA tasks in few secondary schools are not clear. The findings exposed that it was unbearable to identify and differentiate procedures and techniques followed by science teachers in teaching the three science subjects in secondary schools. Despite the fact that physics, chemistry and biology are commonly referred to as science subjects, the subjects are naturally different and this is why they are being taught separately and treated differently. There is a necessity for existence of general and specific procedures and techniques that ought to be followed by science teachers in developing and administering of SBA tasks in order to enhance quality of SBA practices in secondary school in Kilimanjaro region.

The study also concluded that, there is lack of accountability by all stakeholders on the procedures followed by science teachers in developing and administering SBA tasks in secondary schools. The study found out that there was no common understanding among science teachers, heads of schools and academic masters/mistresses about the right procedures and who is leading the procedures. This remark left confusion in the school systems and compromises cooperation among all SBA stakeholders in secondary schools.

Finally, they study concluded that science teachers have open doors to learn procedures and techniques for developing and administering SBA tasks in secondary. The study indicated that science teachers had no enough trainings on SBA practices and indicated their eagerness to learn procedures and techniques for preparing and administering SBA tasks. This comprehension is principally important since the zeal for science teachers to learn new tactics indicated that science teachers are willing to change from their common practices and adopt correct procedures that are triggered to improve the quality of SBA practices in secondary schools in Kilimanjaro region.

\section{Recommendations}

Based on the findings and conclusions of the study, the researcher would like to put forward the following recommendations:

The ministry education through TIE should develop clear guidelines for developing and administering SBA tool and tasks for each science subjects. The guideline should capture should be designed to help science teachers develop SBA tasks that stimulate teaching and learning of cognitive, affective and psychomotor domains across the planned, assessed and taught curricula of the science disciplines. The guideline should also stipulate who will be in charge and enforcer of the 
procedures so as to ensure that SBA tools encompasses of clear students' tasks and activities with high assessment formative aspects.

District and regional education authorities should develop interactive procedures to be followed by science teachers in developing and administering SBA tools formatively in teaching of science subjects in secondary schools. The study also commends that science teachers should be trained on procedures for developing and administering SBA tools through various techniques. Science teachers should be knowledgeable enough to consider both students and administrative demands so as to make SBA tools reflect the competence-based curriculum instead of the content-based set-ups of the current SBA practices.

\section{References}

i. Barnes, N., Fives, H., \&Dacey, C. M. (2015). Teachers' Beliefs about Assessment. In H. Fives, \& M. Gregoire Gill (Eds.). International Handbook of Research on Teacher Beliefs (pp. 284-300). New York: Routledge.

ii. Biggs, J. (1996). Testing: To Educate or Select? Education in Hong Kong at the Crossroads. Hong Kong: Hong Kong Education Publishing Company.

iii. Black, P., \&Wiliam, D. (1998a). Inside The Black Box: Raising Standards through Classroom Assessment. London: NFER Nelson Publishing Co Ltd.

iv. Black, P., \&Wiliam, D. (1998b). Assessment and Classroom Learning: Assessment in Education. Principles, Policy and Practice, 5(1), 18-21.

v. Black, P., \&Wiliam, D. (2010). Inside the black box: Raising standards through classroom assessment. Phi Delta Kappan, 92(1), 81-90. https://doi.org/10.1177/003172171009200119

vi. Bonner, S. M. (2016). Teachers' Perceptions about Assessment: Competing Narratives. In G. T. L. Brown, \& L. R. Harris (Eds.). Handbook of Human and Social Conditions in Assessment (pp. 21-39). New York: Routledge.

vii. Creswell, J. W. (2009). Research Design Qualitative, Quantitative, and Mixed Methods Approach. London, United Kingdom: SAGE Publications Ltd.

viii. Creswell, J. W. (2009). Research Design: Qualitative, Quantitative and Mixed Methods Approaches. Los Angeles: Saga Publications.

ix. Creswell, J. W., \& Creswell, P. N. (2018). Qualitative inquiry and research design: Choosing among five approaches (4thed). Thousand Oaks, CA: Sage.

x. Creswell, W., \& Clark, V. P. (2011). Designing and conducting mixed methods research. London. Sage Publication.

xi. Dixon, H., Hawe, E., \& Parr, J. (2011). Enacting Assessment for Learning: The beliefs practice nexus. Assessment in Education: Principles, Policy\&Practice, 365-379. https://doi.org/10.1080/0969594X.2010.526587

xii. Friyatmi M, D., Rahmi, E., \&Haryanto. (2020). The Development of Computerized Economics Item Banking for Classroom and School-Based Assessment. European Journal of Educational Research, 9(1).

xiii. Fulmer, G.W., Tan K. H. K., and Lee I. C. H. (2019). 'Relationships among Singaporean Secondary Teachers' Conceptions of Assessment and School and Policy Contextual Factors.' Assessment in Education: Principles, Policy \& Practice, 26(2):166-83.

xiv. Hawe, E., \& Dixon, H. (2016). Assessment for learning: A catalyst for student self-regulation. Assessment \& Evaluation in Higher Education, 42, 1-12. https://doi.org/10.1080/02602938.2016.1236360

xv. Hawe, E., \& Dixon, H. (2017). Assessment for Learning: A Catalyst for Student Self-regulation. Assessment \& Evaluation in Higher Education, 42(8), 1181-1192. doi:10.1080/02602938.2016.1236360

xvi. Kauffman, J. R., Jex, S. M., Love, K. G., \&Libkuman, T. M. (1993). The Construct Validity of Assessment Centre Performance Dimensions. International Journal of Selection and Assessment, 1(4), $213-223$. https://doi.org/10.1111/j.1468-2389.1993.tb00115.x

xvii. Kerry, B. (2011). Professional Decision-Making and Risk Assessment. The Australian Journal of Teacher Education, 2(2), 1-9

xviii. Khatab, Z., Abdul. (2012). (PDF) A Study on English Teachers' Assessment Practices on the School-based Assessment for English Language in Malaysia. The Australian Journal of Teacher Education, 2(1), 1-32.

xix. Kyaruzi, F., Strijbos, J. W., Ufer, S., \& Brown, G. T L. (2019): Students' Formative Assessment Perceptions, Feedback Use and Mathematics Performance in Secondary Schools in Tanzania, Assessment in Education: Principles, Policy \& Practice.

xx. Maile, S. (2013). School-Based Quality Assurance of Assessment: An Analysis of Teachers' Practices from Selected Secondary Schools Located in Tshwane North District. International Journal of Humanities and Social Science Invention, 2(10), 15-28. Available from http://www.ijhssi.org/papers/v2(10)/Verson3/C021003015028.pdf

xxi. McMillan, J. M. (2008). Assessment Essentials for Student-based Education(2 ${ }^{\text {nd }}$ ed.). Thousand Oaks: Crown Press. xxii. Ministry of Education and Vocational Training (MoEVT) (2013). Certificate of Secondary Education Examination School Rank. Dar es Salaam: MoEVT.

xxiii. Ministry of Education and Vocational Training (MoEVT) (2014). Sera yaelimunamafunzo [Education training and policy]. Dar es Salaam: MoEVT.

xxiv. Ministry of Education Science and Technology (MoEST) (2017). Education Sector Performance Report. [Education training and policy]. Dar es Salaam: MoEST.

xxv. Mkpae, S. G., \&Adutchay, O. V. (2017). School-Based Assessment: Benefit and Teachers' Perception in Nigerian Secondary Schools. International Journal of Education and Evaluation, 3(2), 19-27. 
xxvi. Ndalichako, J. L. (2014). Examining Classroom Assessment Practices of Secondary School Teachers in Tanzania. National Examinations Council of Tanzania. Retrieved from www.iaea.info/documents/paper_226dc3fd1.pdf

xxvii. NECTA. (2003). Examinations Regulations: Guide for Heads of Schools, Colleges, and Institutes. Dar es Salaam: National Examinations Council of Tanzania Printer.

xxviii. NECTA. (2003). Examinations Regulations: Guide for Heads of Schools, Colleges, and Institutes. Dar es Salaam: National Examinations Council of Tanzania Printer.

xxix. Nichols, S. L., \& Harris, L. R. (2016). Accountability Assessment's Effects on Teachers and Schools. In G. T. L. Brown, \& L. R. Harris (Eds.). Handbook of human and social conditions in assessment (pp. 40-56). New York: Routledge.

xxx. O’Malley, M. D., Wolf-Prusan, L., Lima Rodriguez, C., Xiong, R., \&Swarts, M. R. (2019). Cultural-Competence Considerations for Contemporary School-Based Threat Assessment. Psychology in the Schools, 56(2), $255-275$.

xxxi. OlufunmilayoAduloju, M., Adikwu, O., \&IpoyiAgi, C. (2016). Steps in Carrying Out School Based Assessment: Implication for National Development. Open Access Library Journal, 03(03), 1.

xxxii. Opara, I. M., Onyekuru, B. U., \&Njoku, J. U. (2015). Predictive Power of School Based Assessment Scores on Students' Achievement in Junior Secondary Certificate Examination (JSCE) In English and Mathematics. Journal of Education and Practice, 6(9), 6.

xxxiii. Ottevanger, W., J. Akker\& L. Feiter. (2007). Developing Science, Mathematics, and ICT Education in Sub-Saharan Africa: Patterns and Promising Practices (Working Paper No. 101). Washington, DC: The World Bank.

xxxiv. Paulo. S. (2015). Effects of Frequent Classroom Teaching on Students Mathematics Achievement in Ordinary Level Secondary Schools I Monduli District, Arusha-Tanzania. Mwenge Catholic University. Moshi

xxxv. Poliah, R. (2010). The Management of Quality Assurance of School Based Assessment at National Level in South Africa. Unpublished Doctoral Dissertation. University of Johannesburg, Johannesburg, South Africa. Available from http://hdl.handle.net/10210/3688

xxxvi. Porter, A.C. \& Smithson, J.L. (2001). Defining, Developing, and Using Curriculum Indicators. CPRE Research Report Series RR-048. Philadelphia, PA: University of Pennsylvania, Consortium for Policy Research in Education.

xxxvii. Schneider, M. and Somers, M. (2006) Organizations as Complex Adaptive Systems: Implications for Complexity Theory for Leadership Research. The Leadership Quarterly, 17, 351365.https://doi.org/10.1016/j.leaqua.2006.04.006

xxxviii. Taras, M. (2009). Summative Assessment: The Missing Link for Formative Assessment. Journal of Further and Higher Education 33(1): 57-69.

xxxix. Terra, L. A. A., \&Passador, J. L. (2015). A phenomenological approach to the study of social systems. System Practice and Action Research. 8(2). 1-14.

xl. Wiliam, D., \& Thompson, M. (2007). Integrating Assessment with Instruction: What Will It Take to Make It Work? In C. A. Dwyer (Eds.), The Future of Assessment:Shaping Teaching and Learning (pp. 53-82). Mahwah, NJ: Lawrence Erlbaum Associates.

xli. Zembazemba, R. D. (2017). Educational Assessment Practices in Tanzania: A Critical Reflection. Business Education Journal, 1(3), 1-8. 